\title{
A new species of Aphanotorulus (Siluriformes: Loricariidae) from the rio Aripuanã basin, Brazil
}

\author{
Andreza S. Oliveira ${ }^{1}$, Lúcia Rapp Py-Daniel ${ }^{2}$ and Cláudio H. Zawadzki ${ }^{3}$
}

The cis-Andean genus Aphanotorulus was recently revised and comprises six valid species: A. ammophilus, A. emarginatus, A. gomesi, A. horridus, A. phrixosoma and A. unicolor. Herein, a new species is described from tributaries of the rio Aripuanã basin, in Amazonas and Mato Grosso states, Brazil. The new species is easily distinguished from congeners by its color pattern: caudal fin with upper lobe mostly hyaline with dark spots along rays and membranes, and lower lobe red and without dark spots; and absence of dark spots in the lateral series of mid-ventral plates.

Keywords: Amazon basin, Fishes, Hypostominae, Taxonomy.

O gênero cisandino Aphanotorulus foi recentemente revisado e consiste de seis espécies válidas: A. ammophilus, A. emarginatus, A. gomesi, A. horridus, A. phrixosoma e A. unicolor. No presente trabalho, uma nova espécie é descrita dos tributários da bacia do rio Aripuanã, nos estados do Amazonas e Mato Grosso, Brasil. A nova espécie é facilmente distinguida de suas congêneres pelo padrão de coloração: nadadeira caudal com o lobo superior quase totalmente hialino e com pintas escuras ao longo dos raios e membranas, e o lobo inferior vermelho e desprovido de pintas; ausência de manchas escuras na série lateral de placas medianas ventrais.

Palavras-chave: Bacia Amazônica, Hypostominae, Peixes, Taxonomia.

\section{Introduction}

The genus Aphanotorulus Isbrücker \& Nijssen, 1983 is distinguished from most hypostomines by an elongate body with a cream-colored background completely covered by round or elongate dark spots. Aphanotorulus includes medium to large size species that vary from $150 \mathrm{~mm}$ to $500 \mathrm{~mm}$ in total length, and have a moderately depressed body, ventrally flat caudal peduncle, and large fins. The caudal fin is particularly large and, in some species, strongly forked. Representatives of this genus, formerly known as the Hypostomus emarginatus group, have a convoluted taxonomic history during which a variety of nomenclatural arrangements have been proposed (see Ray, Armbruster, 2016 for a brief review).

Aphanotorulus was originally distinguished from the genus Hypostomus by the presence of numerous buccal papillae on the oral cavity (vs. a single papillae); short body up to $150 \mathrm{~mm}$ SL (vs. usually $>150 \mathrm{~mm}$ SL in almost all Hypostomus); elongate hypobranchials (vs. short and stocky); and sex-related hypertrophied odontodes over the entire body surface (vs. sexual dimorphism not involving the elongation of odontodes over the entire body) (Armbruster, Page, 1996).

Two other genera have been proposed to accommodate these elongate-bodied and light-colored hypostomines: Squaliforma Isbrücker \& Michels, 2001 comprising of Squaliforma annae (Steindachner, 1881), S. biseriata (Cope, 1872), S. emarginata (Valenciennes, 1840), S. gomesi (Fowler, 1941), S. horrida (Kner, 1854), S. phrixosoma (Fowler, 1940), S. scopularia (Cope, 1871), S. squalina (Jardine, 1841), S. tenuis (Boeseman, 1968), S. tenuicauda (Steindachner, 1878), S. villarsi (Lutken, 1874) and $S$. virescens (Cope, 1874) (Weber, 2003; Ferraris, 2007) and Isorineloricaria Isbrücker, 1980, with one very elongate trans-andean representative, Isorineloricaria spinosissima (Steindachner, 1880).

\footnotetext{
${ }^{1}$ Programa de Pós-Graduação em Biologia de Água Doce e Pesca Interior, Instituto Nacional de Pesquisas da Amazônia, Av. André Araújo, 2936, Petrópolis, Caixa Postal 2223,69060-001 Manaus, AM, Brazil. andreza.santoli@gmail.com (corresponding author)

${ }^{2}$ Coleção de Peixes, Programa de Coleções Científicas, Coordenação de Biodiversidade (CBio), Instituto Nacional de Pesquisas da Amazônia, Av. André Araújo, 2936, Petrópolis, Caixa Postal 2223, 69060-001 Manaus, AM, Brazil. lucia.rapp@gmail.com ${ }^{3}$ Departamento de Biologia, Núcleo de Pesquisas em Limnologia, Ictiologia e Aquicultura (Nupélia), Universidade Estadual de Maringá. Av. Colombo 5790, G90 s18B, 87020-900 Maringá, PR, Brazil. chzawadzki@hotmail.com
} 
In 2004, Armbruster in a morphology-based cladistic analysis of Hypostominae including Aphanotorulus ammophilus Armbruster \& Page, 1996, A. unicolor (Steindachner, 1908), Hypostomus emarginatus (1 and 2), H. squalinus and Isorineloricaria spinosissima, observed the paraphyly of this group inserted inside a large Hypostomus clade.

Lujan et al. (2015), in a molecular phylogeny using both Bayesian Inference and Maximum Likelihood methods, erected a new division for the tribe Hypostomini: Hypostomus continued to be monophyletic with exclusion of the species in the Hypostomus emarginatus group: Aphanotorulus ammophilus, A. emarginatus n. comb., A. squalinus n. comb. and Isorineloricaria spinosissima. All analyzed members of the Hypostomus emarginatus group emerged as being more closely related to members of the Peckoltia Clade (Bayesian posterior probability, $\mathrm{BPP}=1$, Maximum likelihood bootstrap, MLB = 95) than of the Hypostomini Clade. Support for this analysis was strong for Aphanotorulus (BPP $=1, \mathrm{MLB}=$ 99); however, support for the monophyly of Aphanotorulus emarginatus and A. squalinus in the analysis was weak. Therefore, based on molecular analysis, Lujan et al. (2015) recognized the species of Squaliforma in Aphanotorulus.

More recently, Ray, Armbruster (2016), following Lujan et al. (2015), revised the former Hypostomus emarginatus group and, based on external morphology, proposed that the trans-Andean Isorineloricaria should comprise four valid species, I. acuarius Ray \& Armbruster, 2016, I. spinosissima, I. tenuicauda, I. villarsi; the cisAndean Aphanotorulus should include six valid species, A. ammophilus, A. emarginatus, A. gomesi, A. horridus, A. phrixosoma and A. unicolor; and that the genus Squaliforma should be invalidated.

For this new arrangement, Ray, Armbruster (op cit.), proposed that Aphanotorulus be distinguished from Isorineloricaria by a caudal peduncle oval in cross section and not greatly elongated (vs. caudal peduncle round in cross-section and proportionately longer), and by the presence of small dark spots (less than half lateral plate diameter) on a light tan background (vs. spots almost as large as lateral plates on a nearly white background). Here, based on recently collected material, we describe a new species of Aphanotorulus from the rio Aripuanã basin.

\section{Material and Methods}

Measurements and counts follow Boeseman (1968), modified from Weber (1985) and Zawadzki et al. (2008); the latter authors added the width and length of the lower lip. Measures were taken from the left side of the body, whenever possible. Plate counts and nomenclature follow Schaefer (1997) and Oyakawa et al. (2005). Standard length (SL) is expressed in millimeters and all other measurements are expressed as percentages of standard length or head length (HL). All measurements were taken point to point to the nearest $0.1 \mathrm{~mm}$ with digital calipers.
Institutional abbreviations are: AMNH, American Museum of Natural History, New York; ANSP, Academy of Natural Sciences of Drexel University, Philadelphia; BMNH, Natural History Museum, London; CAS, California Academy of Sciences, San Francisco; DZSJRP, Departamento de Zoologia e Botânica, Universidade Estadual Paulista "Júlio de Mesquita Filho", São José do Rio Preto; INPA, Instituto Nacional de Pesquisas da Amazônia, Manaus; LBP, Laboratório de Biologia e Genética de Peixes, Universidade Estadual Paulista "Júlio de Mesquita Filho", Botucatu; MCP, Museu de Ciências e Tecnologia, Pontifícia Universidade Católica do Rio Grande do Sul, Porto Alegre; MNRJ, Museu Nacional, Universidade Federal do Rio de Janeiro, Rio de Janeiro; MZUSP, Museu de Zoologia, Universidade de São Paulo, São Paulo; NMW, Naturhistorisches Museum, Wien; NUP, Coleção Ictiológica do Núcleo de Pesquisas em Limnologia, Ictiologia e Aquicultura, Universidade Estadual de Maringá, Maringá; UFRO-I, Coleção Ictiológica, Universidade Federal de Rondônia, Porto Velho; USNM, National Museum of Natural History, Smithsonian Institution, Washington DC; RMNH, National Natuurhistorisch Museum, Leiden; ZUEC, Museu de Zoologia da Universidade Estadual de Campinas “Adão José Cardoso", Campinas.

\section{Results}

\section{Aphanotorulus rubrocauda, new species}

urn:1sid:zoobank.org:act:E3B44D1F-C9B4-45A1-AF13AB4F1AB40F65

\section{Figs. 1-2}

Hypostomus emarginatus. -Pedroza et al., 2012: 13 [species list; rio Guariba and rio Roosevelt, tributaries of rio Aripuanã basin]

Aphanotorulus horridus. -Ray, Armbruster, 2016: 521 [taxonomic revision of Aphanotorulus and Isorineloricaria].

Holotype. INPA 33666, 150.5 mm SL, Brazil, Amazonas State, Apuí Municipality, rio Guariba, Resex do Guariba, tributary of the rio Aripuanã basin, $08^{\circ} 45^{\prime} 44^{\prime \prime} \mathrm{S} 60^{\circ} 24^{\prime} 48^{\prime \prime} \mathrm{W}$, 15 Nov 2008, W. S. Pedroza, W. M. Ohara, F. R. V. Ribeiro \& T. F. Teixeira.

Paratypes. All from Brazil. Rio Aripuanã basin: Amazonas State: INPA 33636, 5, 150.2-220.3 mm SL (1 c\&s, $150.2 \mathrm{~mm} \mathrm{SL}$ ), Apuí Municipality, rio Guariba, Resex (Extractive Reserve) do Guariba, tributary of the rio Aripuanã basin, $08^{\circ} 45^{\prime} 03^{\prime \prime}$ S 60²6'10”W, 07 Nov 2008, W. S. Pedroza, W. M. Ohara, F. R. V. Ribeiro \& T. F. Teixeira. INPA 52205, 1, $187.4 \mathrm{~mm}$ SL (same data of the holotype). INPA 52436, 2, 69.3-86.9 mm SL, Novo Aripuanã, boulders on rapids above Prainha, $07^{\circ} 17^{\prime} 13.00^{\prime \prime} \mathrm{S}$ 60³7'59.0”'W, Nov 2014, E. D. Ribeiro, R. Collins \& V. Machado. INPA 52448, 3, 145.8-195.0 mm SL, Novo Aripuanã Municipality, boulders on rapids below Prainha, $06^{\circ} 59^{\prime} 56.00^{\prime \prime}$ 6 6040'9.00”W, Nov 


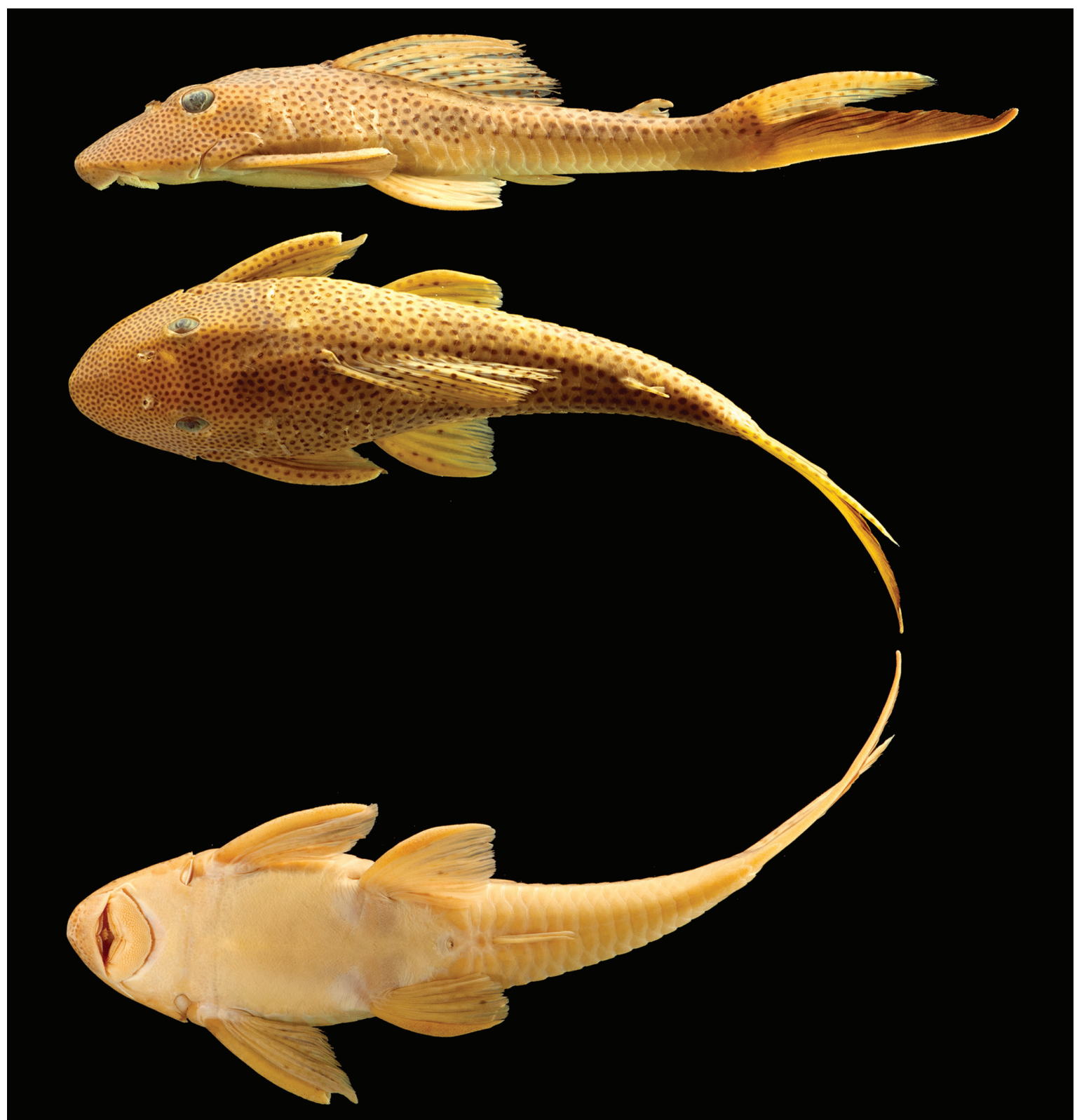

Fig. 1. Holotype of Aphanotorulus rubrocauda, INPA 33666, 150.5 mm SL, Brazil, Amazonas State, Apuí Municipality, Resex do Guariba, rio Aripuanã drainage, tributary of the rio Madeira basin, in lateral, dorsal, and ventral views.

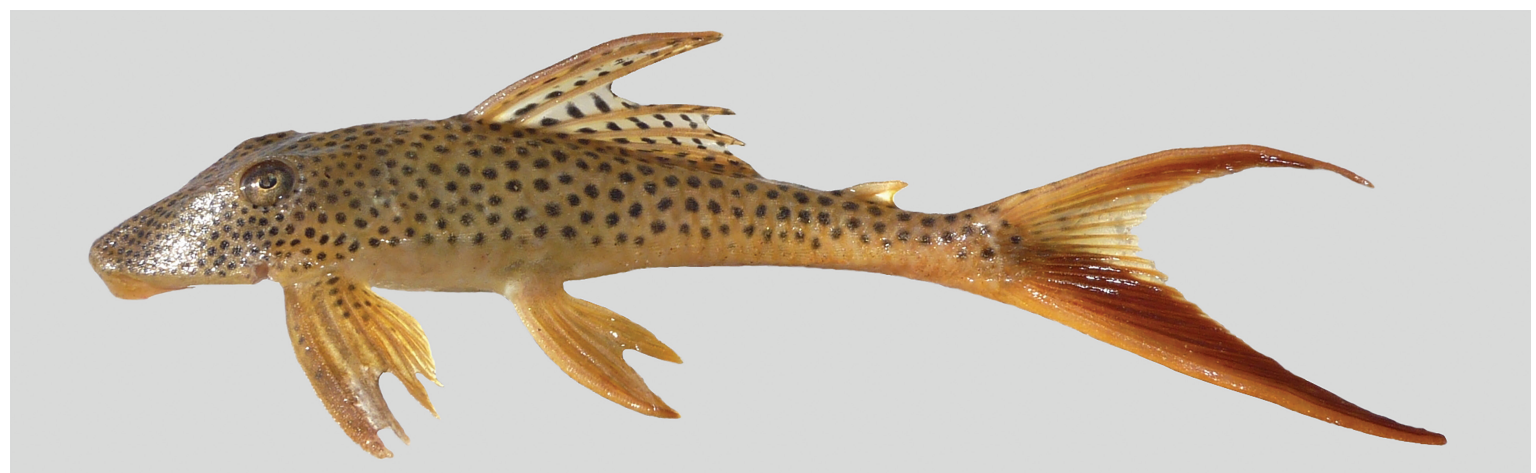

Fig. 2. Lateral view of Aphanotorulus rubrocauda, MNRJ 37551, paratype, $118.6 \mathrm{~mm} \mathrm{SL}$, Brazil, Mato Grosso State, Aripuanã Municipality, rio Aripuanã basin, 500 meters downstream of the rapids of Dardanelos waterfalls. Photographed alive by Fabio Pupo. 
2014, E. D. Ribeiro, R. Collins \& V. Machado. Mato Grosso State: INPA 31868, 1, 173.2 mm SL, Aripuanã Municipality, Cisga, 1009'9.23'S 59²6'9.40'”, 29 Sep 1975, F. Marinho. MNRJ 36331, 2, 182.4-218.0 mm SL, Aripuanã Municipality, about 100 meters downstream of Dardanelos waterfalls, 109'48”S 59²6'56”W, 31 Mar 2008, F. Pupo \& R. Paiva. MNRJ 37551, 1, 118.6 mm SL, Aripuanã Municipality, rio Aripuanã, 500 meters downstream of Dardanelos waterfalls, 1009'47'S 59²6'41'W, 05 May 2009, F. Pupo. MNRJ 38829, 1, 95.6 mm SL, Aripuanã Municipality, rio Aripuanã, left margin, 1500 meters downstream of Dardanelos waterfalls, 1009'33'S 59²6'20'W, 09 Feb 2011, F. Pupo. MNRJ 38943, 2, 173.5-222.5 mm SL, Aripuanã Municipality, left margin, 1500 meters downstream of Dardanelos waterfalls, 1009'30'S 59²6'19'W, 11 Dec 2008, F. Pupo. MNRJ 39824, 3, 132.2-180.5 mm SL, Aripuanã Municipality, rio Aripuanã, left margin, 500 meters downstream of Dardanelos waterfalls, $10^{\circ} 09^{\prime} 53$ 'S 59 26'57'W, 20 Dec 2010, F. Pupo. MZUSP 37594, 5, 155.9-226.5 mm SL, Aripuanã Municipality, rio Aripuanã, 3 kilometers downstream of the Cachoeira Grande, 0957'23.7'S 59¹9'45.9'W, 08 Nov 1976, Expedição MZUSP/INPA. MZUSP 60372, 1, $144.0 \mathrm{~mm}$ SL, Aripuanã Municipality, Porto de Balsa (upstream), road connecting the district of Colniza Panelas, kilometer 18, 09²1'10.5'S 59¹9'32.3'W, 22 Jul 1997, F. Machado. MZUSP 104456, 5, 192.5-239.2 mm SL, Aripuanã Municipality, 3 kilometers below of the Cachoeira Grande (Dardanelos waterfalls), 1009'00”S 59²6’00”W, 07 Nov 1976, Expedição MZUSP/INPA. NUP 7458, 4, 125.3-215.5 mm SL, Aripuanã Municipality, small stream with unknown name, tributary of igarapé Guaribal, $10^{\circ} 06 ’ 35^{\prime}$ 'S 59 $26^{\prime} 12^{\prime \prime} \mathrm{W}$, 19 May 2008, I. M. Fernandes. NUP 7785, 6, 158.5-234.5 mm SL, Aripuanã Municipality, unnamed small stream, tributary of igarapé Guaribal, $10^{\circ} 06^{\prime} 35^{\prime} \mathrm{S} 59^{\circ} 26^{\prime} 12^{\prime \prime} \mathrm{W}$,
19 May 2008, I. M. Fernandes. UFRO-I 21197, 5, 158.6212.5 mm SL, Rondolândia Municipality, rio Madeirinha, boulders on rapids, 40 minutes motorized canoe, above of the Comil farm, 09²4'42.2'S 61²2'0.4'W, 12 Jul 2013, D. G. Hungria. UFRO-I 21647, 2, 132.6-159.8 mm SL, Colniza Municipality, rio Roosevelt, boulders on rapids, $09^{\circ} 09^{\prime} 48.7^{\prime \prime} \mathrm{S}$ $60^{\circ} 44^{\prime} 33.5^{\prime}$ 'W, 13 Jul 2013, W. M. Ohara. UFRO-I 21648, 1, $126.2 \mathrm{~mm}$ SL, Colniza Municipality, rio Branco, $09^{\circ} 08^{\prime} 43.1^{\prime \prime} \mathrm{S}$ $60^{\circ} 45^{\prime} 03.5^{\prime} \mathrm{W}, 14 \mathrm{Jul}$ 2013, W. M. Ohara. UFRO-I 21672 , 5, 72.4-240.5 mm SL, Colniza Municipality, rio Roosevelt, 0908'43.1'S 6045'03.5'W, 14 Jul 2013, B. S. F. Barros. UFRO-I 22039, 1, 91.0 mm SL, Colniza Municipality, rio Roosevelt, 0909'46.82'S 6044'31.43”W, 14 Jul 2013, D. G. Hungria. UFRO-I 22081, 1, 156.7 mm SL, Colniza Municipality, boulders on rapids in the rio Aripuanã, Pai da Mata farm, 09¹5'45.79'S 59²3'10.6”W, 17 Jul 2013, D. G. Hungria. UFRO-I 22685, 5, 172.7-238.5 mm SL, Colniza Municipality, boulders on rapids in the rio Aripuanã, farm Pai da Mata, 09¹5'45.79’S 59²3'10.60”W, 17 Jul 2013, D. G. Hungria.

Diagnosis. Aphanotorulus rubrocauda can be distinguished from all other species of Aphanotorulus by its color pattern: having a uniformly red colored lower caudal-fin lobe (vs. lower lobe of caudal fin with dark spots on creamy colored background), by the absence of dark spots on the posterior half of mid-ventral lateral plate series ( $v s$. presence of dark spots in all lateral plate series). Additionally, Aphanotorulus rubrocauda is distinguished from congeners by having more premaxillary teeth $(32-65$ per ramus, mean $=45$; vs. $15-34$, mean $=24)$ and dentary teeth $(30-63$ per ramus, mean $=44$; vs. 14-34, mean =25). Aphanotorulus rubrocauda further differs from $A$. emarginatus by having small round dark spots (vs. dark large and elongated spots) (Fig. 3).

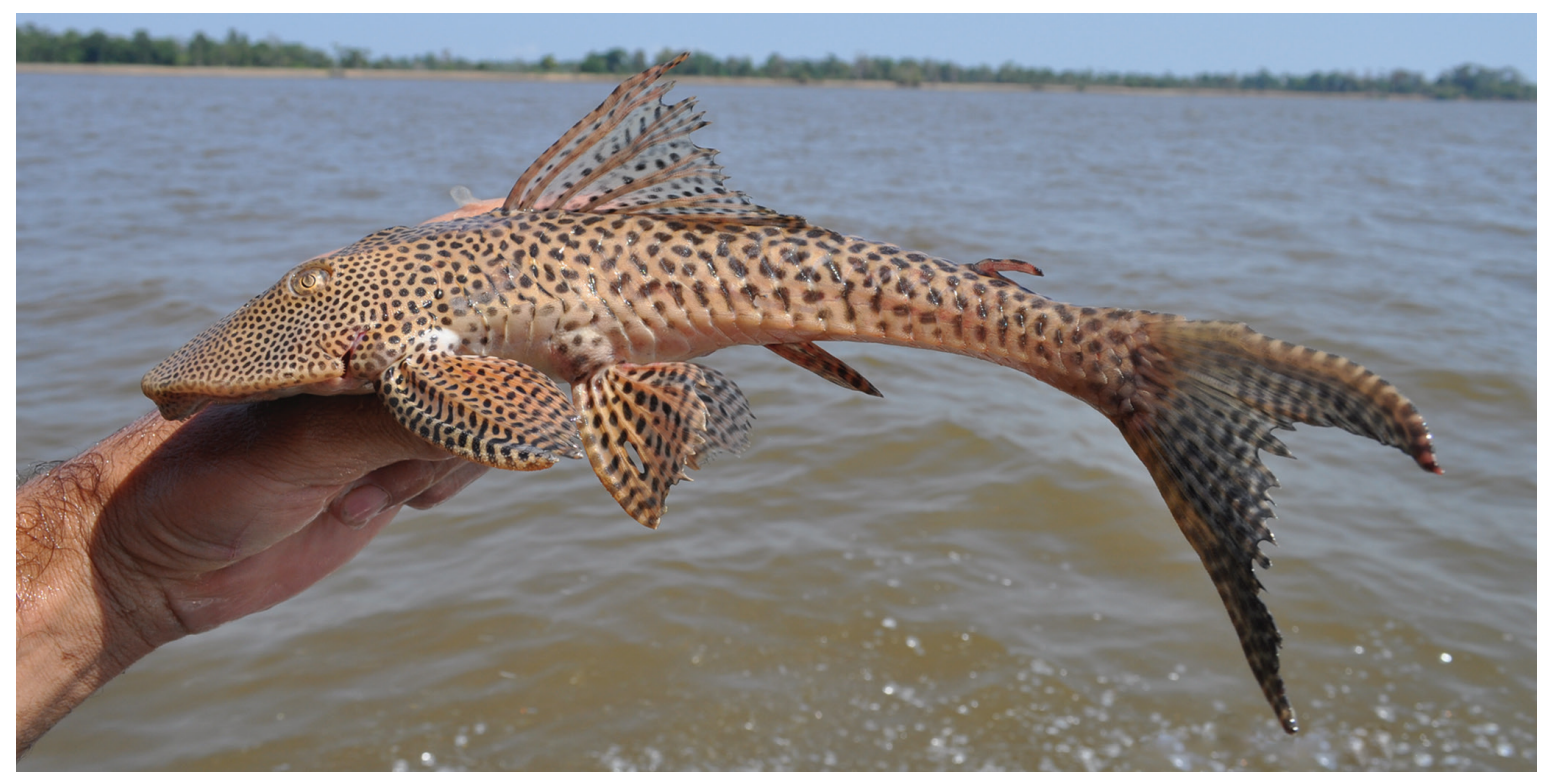

Fig. 3. Lateral view of Aphanotorulus emarginatus, NUP 17748, 257.3 mm SL, Brazil, Amazonas State, Parintins Municipality, Paraná do Ramos, rio Amazon basin. Photographed alive by Hugmar Pains da Silva. 
Description. Morphometric and count data are given in Tab. 1. Long and moderately depressed body in lateral view; body trapezoid in cross section. Dorsal profile slightly convex from snout to dorsal-fin origin, then descending almost straight to caudal-fin procurrent ray and rising again to caudal-fin origin. Ventral profile straight from snout to caudalfin origin. Median series of plates slightly carenate; midventral series not forming prominent keel. Greatest body width anterior to cleithral region. Scapular girdle and abdominal surfaces covered by small plates of uniform size. First anal-fin pterygiophore exposed, located anterior to anal-fin origin, in ventral view. Three pre-dorsal plates. Supraoccipital usually with small median ridge and bordered by three plates. Nine plates between dorsal and adipose fin. Seven plates at dorsalfin base. Median series with 28 perforated plates.

Head short, depressed and triangular in dorsal view. Snout tip slightly rounded with small odontodes. Orbit slightly elevated, bordered by small odontodes; flat interorbital region. Eyes moderately large (15.1-22.1\% in HL). Maxillary barbel short, cylindrical, not reaching transverse line on lower lip edge. Presence of large buccal papilla, square and wide, covered distally by multiple small papillae. Mouth wide. Upper lip rounded in ventral view and without marginal fringes. Lower lip rounded and covered with papilla, decreasing in size distally. Odontodes present on anterior surface of snout ventral edge. Cheek plates with non-evertible odontodes usually small; more developed in reproductive males.

Bicuspid teeth; mesial cusp longer and rounded, two times larger than lateral teeth; lateral cusp pointed. Teeth stalk hyaline; crown yellow. Mature males, with mesial cusp more elongated, up to three times longer than lateral. Premaxilla with 33-57 teeth (mode $=45, \mathrm{n}=62$ ), dentary with 31-58 teeth $($ mode $=44, \mathrm{n}=62)$.

Tab. 1. Morphometric data and meristics of Aphanotorulus rubrocauda, new species.

\begin{tabular}{|c|c|c|c|c|}
\hline & Holotype & $\mathrm{N}$ & Range & Mean/SD \\
\hline Standard length $(\mathrm{mm})$ & 200.9 & 62 & $72.4-240.5$ & \\
\hline \multicolumn{5}{|c|}{ Percents of standard length } \\
\hline Head length & 30.8 & 62 & $26.5-33.7$ & $29.6 \pm 1.5$ \\
\hline Predorsal length & 36.9 & 62 & $34.3-39.5$ & $36.3 \pm 1.3$ \\
\hline Snout length & 17.3 & 62 & $16.1-20.2$ & $18.3 \pm 0.9$ \\
\hline Cleithral width & 26.5 & 62 & $23.5-27.8$ & $25.3 \pm 1.0$ \\
\hline Dorsal-fin base length & 22.2 & 62 & $19.3-23.9$ & $21.5 \pm 1.1$ \\
\hline Interdorsal length & 24.9 & 62 & $21.2-27.6$ & $24.7 \pm 1.4$ \\
\hline Caudal-peduncle length & 36.8 & 62 & $32.2-37.9$ & $36.0 \pm 1.2$ \\
\hline Caudal-peduncle depth & 7.9 & 62 & $6.9-9.0$ & $7.5 \pm 0.3$ \\
\hline Dorsal-fin spine length & 28.3 & 61 & $24.2-32.4$ & $28.4 \pm 1.9$ \\
\hline Pectoral-fin spine length & 24.6 & 62 & $21.6-28.4$ & $25.1 \pm 1.5$ \\
\hline Pelvic-fin spine length & 21.5 & 62 & $18.9-23.4$ & $21.5 \pm 1.1$ \\
\hline Thoracic length & 24.5 & 62 & $20.3-25.6$ & $22.6 \pm 1.2$ \\
\hline Abdominal length & 22.3 & 62 & $18.2-22.3$ & $19.8 \pm 0.8$ \\
\hline Upper caudal-fin unbrached ray length & 26.3 & 55 & $17.6-41.7$ & $29.8 \pm 5.3$ \\
\hline Lower caudal-fin unbranched ray length & 31.7 & 54 & $23.7-44.8$ & $35.1 \pm 4.7$ \\
\hline \multicolumn{5}{|c|}{ Percents of head length } \\
\hline Head depth & 53.2 & 62 & $44.3-59.1$ & $51.5 \pm 2.8$ \\
\hline Cleithral width & 86.3 & 62 & $79.5-95.9$ & $85.5 \pm 2.9$ \\
\hline Snout length & 56.1 & 62 & $54.9-72.3$ & $61.8 \pm 2.8$ \\
\hline Orbital diameter & 18.5 & 62 & $15.1-22.1$ & $18.3 \pm 1.4$ \\
\hline Interorbital width & 37.9 & 62 & $33.6-41.1$ & $37.3 \pm 1.4$ \\
\hline Interdorsal length & 80.9 & 62 & $64.8-103.0$ & $83.9 \pm 8.2$ \\
\hline Premaxillary length & 13.8 & 62 & $13.0-17.8$ & $14.7 \pm 1.1$ \\
\hline Dentary length & 12.9 & 62 & $11.4-16.8$ & $13.8 \pm 1.2$ \\
\hline Lip width & 45.6 & 62 & $37.2-52.8$ & $44.7 \pm 3.3$ \\
\hline Lower-lip length & 13.8 & 62 & $9.7-18.2$ & $13.9 \pm 2.0$ \\
\hline Barbel length & 14.8 & 61 & $6.7-16.7$ & $11.6 \pm 2.1$ \\
\hline \multicolumn{4}{|c|}{ Counts } & Mode \\
\hline Median plate series & 29 & 62 & $28-30$ & 28 \\
\hline Plates limiting supraoccipital & 3 & 62 & $4-6$ & 4 \\
\hline Plates between dorsal and adipose fin & 9 & 62 & $8-10$ & 9 \\
\hline Dorsal plates below dorsal-fin base & 7 & 62 & $7-8$ & 7 \\
\hline Premaxillary teeth & 57 & 62 & $33-57$ & 45 \\
\hline Dentary teeth & 54 & 62 & $31-58$ & 44 \\
\hline
\end{tabular}


Dorsal fin II,7, branched rays decreasing in length posteriorly. Last branched ray $2 / 3$ shorter than dorsal-fin spine. Pectoral fin I,6; distal tip of branched rays surpassing insertion of pelvic fin; pectoral-fin spine slightly curved inward and depressed, distal region with hypertrophied odontodes along laterodorsal surface in larger specimens. Pelvic fin i,5, distal tip of branched rays reaching insertion of anal-fin. Pelvic fin unbranched ray slightly curved inward and rounded with thin extremity. Forked caudal fin i,14,i. Unbranched ray of lower lobe slightly longer than that from upper lobe. All rays with small odontodes. Caudal fin with seven branched rays in each lobe. Anal-fin branched rays of coequal length.

Coloration in alcohol. Body with light brown base color covered with rounded dark spots; spots slightly smaller and more densely organized on head than on trunk and fins. Distal portion of pectoral and pelvic fins hyaline and without dark spots. Dorsal-fin spine with 16-17 spots, inter radial membranes with 10-11 spots each; branched rays uniformly colored. Spots on pectoral fin arranged from insertion to distal end of all fin rays. Pelvic fin with spots from insertion to distal third; plain or hyaline along margin. Presence of dark spots on lateral series of plates, except on mid-ventral and ventral series. Upper lobe of caudal fin cream colored with dark spots on simple and branched rays; lower lobe lacking spots, uniformly reddish to brown. Red coloration on lower caudal fin lobe restricted to branched rays; unbranched ray almost uniform. Dark spots on body and fins becoming more numerous in adults (Figs. 1-2).
Coloration in life. Similar to preserved specimens, but more intensely red on lower lobe of caudal fin. In juveniles (up to $110.0 \mathrm{~mm} \mathrm{SL}$ ) both lobes are red, with a few dark spots on base of upper lobe. In adults only the lower lobe is red, whereas the upper lobe has more sparsely distributed spots for its entire extension (Fig. 2).

Geographical distribution and ecological notes. The new species was found in fast-running waters of tributaries of the rio Aripuanã basin, a right bank tributary of the rio Madeira that stretches from the Mato Grosso to Amazonas States (Fig. 4). The rio Aripuanã is a dark-colored water river, poor in sediments, having cataracts, large boulders and a rocky bottom from its middle reach upward, stretching approximately $800 \mathrm{~km}$ from its headwaters until its confluence with the sediment-loaded rio Madeira. The rio Aripuanã receives many clear-water, rocky-bottom tributaries that drain the Brazilian Shield.

Etymology. The specific epithet, rubrocauda, is from the Latin rubro, meaning red, and cauda referring to caudal fin.

Conservation status. Aphanotorulus rubrocauda, under the IUCN standards, should be considered as a Least Concern species (LC). The species occurs in preserved areas; it is frequently seen although not abundant. No current threats were identified that could endanger the species for now.

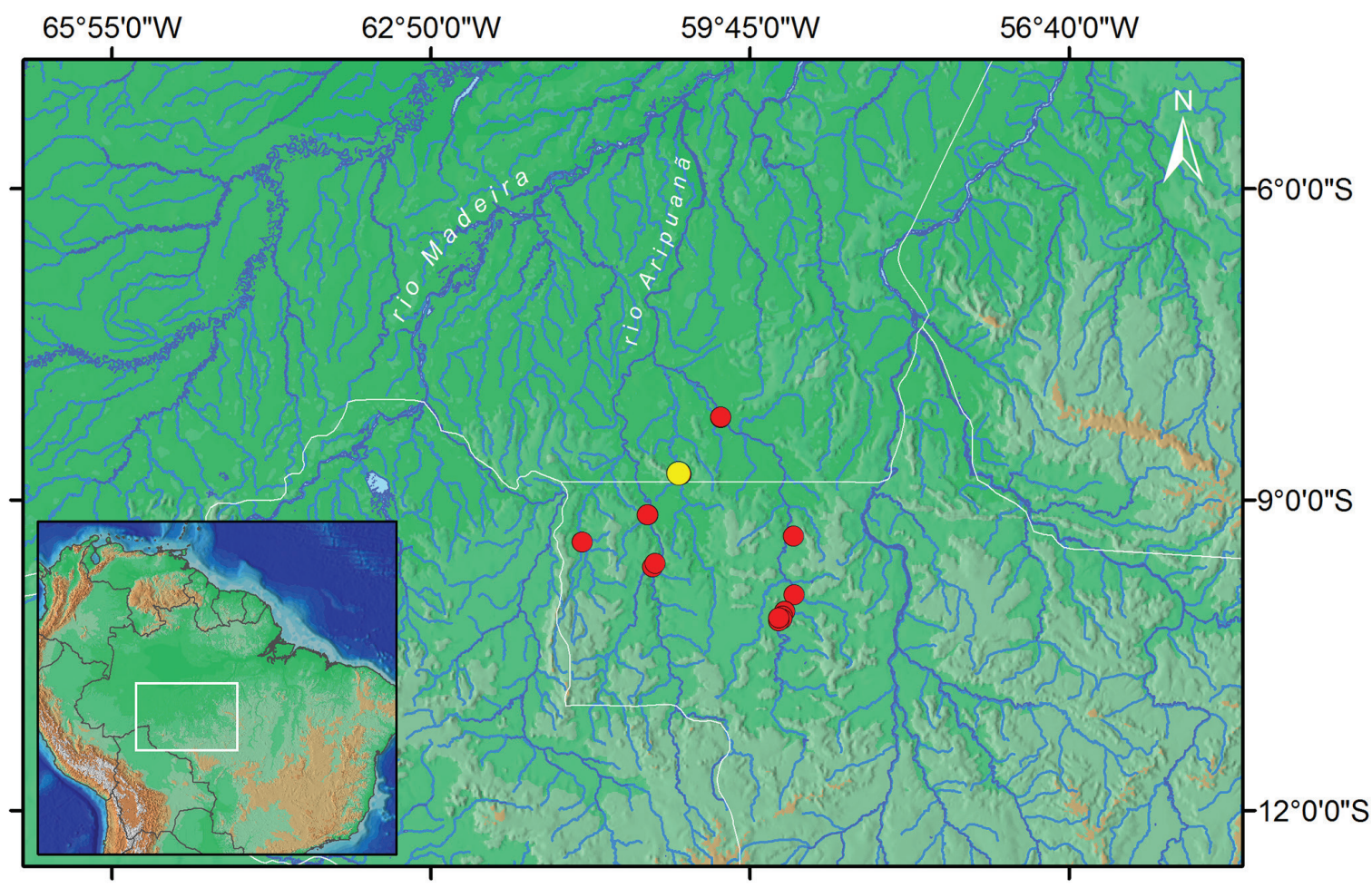

Fig. 4. Distribution of Aphanotorulus rubrocauda in the rio Aripuanã basin. Type locality is represented by the yellow circle. Some symbols represent more than one lot or locality. 
Comparative material examined. Aphanotorulus emarginatus: Brazil: DZSJRP 3920, 1, 171 mm SL. LBP 17160, 2, 134.9-158.1 mm SL. LBP 17182, 2, 116.1-125.4 mm SL. INPA 22138, 1, 270.1 mm SL. INPA 25716, 1, 168.2 mm SL. INPA 28771, 5, 78.9-206.5 mm SL. INPA 36082, 1, 272.5 mm SL. INPA 36637, 2, 165.7-179.6 mm SL. MCP 30623, 1, 132.4 mm SL. MZUSP 40908, 1, 149.6 mm SL. MZUSP 82178, 4, 257.5- 324.5 mm SL. MZUSP 82247, 9, 90.9103.8 mm SL. NUP 9257, 1, 146.3 mm SL. NUP 10951, 1, 186.5 mm SL. Colombia: USNM 181367, 1, 194.0 mm SL. Venezuela: ANSP 185287, 1, $118.8 \mathrm{~mm}$ SL. Aphanotorulus phrixosoma. Brazil: ANSP 68650, 1, $110.6 \mathrm{~mm}$ SL, holotype of Plecostomus phrixosoma Fowler, 1940a: 233. AMNH 12604, 1, 165.2 mm SL. LBP 166, 5, 105.1-147.6 mm SL. MZUSP 49839, 1, 191.5 mm SL. MZUSP 50378, 1, 146.8 mm SL. MZUSP 50493, 1, 173.0 mm SL. MZUSP 50495, 1, 157.0 mm SL. Peru. ANSP 73174, 2, 117.6-122.9 mm SL. USNM 167887, 2, 125.0-186.93 mm SL. Aphanotorulus unicolor. Brazil: INPA 24951, 3, 48.2-92.2 mm SL. MZUSP 49659, 6, 51.4-87.7 mm SL. MZUSP 49682, 3, 50.2-125.6 mm SL. MZUSP 50488, 1, $108.6 \mathrm{~mm}$ SL. UFRO-I 6096, 1, 107.2 mm SL. UFRO-I 6104, 5, 77.8-93.8 mm SL. UFRO-I 6107, 1, 92.5 mm SL. Hypostomus carinatus. Brazil: INPA 41833, 2, 156.5-166 mm SL. Hypostomus cochliodon. Brazil: NUP 12069, 2, 125.5-151.5 mm SL. NUP 12071, 2, 145.5-151.3 mm SL. NUP 12670, 1, 155.5 mm SL. NUP 13479, 5, 49.0-160.8 mm SL. Hypostomus delimai. Brazil: ANSP 192612, 1, $202.1 \mathrm{~mm} \mathrm{SL}$, paratype of Hypostomus delimai Zawadzki, de Oliveira \& Debona, 2013: 74. INPA 20473, 1, $167.1 \mathrm{~mm}$ SL, paratype of Hypostomus delimai Zawadzki, de Oliveira \& Debona, 2013: 74. ZUEC 7088, 1, 200.7 mm SL. Hypostomus faveolus. Brazil: INPA 20069, 1, 145.1 mm SL. INPA 20452, 1, 168.4 mm SL. Hypostomus hoplonites. Brazil: INPA 2372, 1, 168.9 mm SL. INPA 35309, 2, 101.1-173.3 mm SL. Hypostomus macushi. Brazil: INPA 2559, 1, 148.2 mm SL. Hypostomus cf. pantherinus. Brazil: INPA 35312, 1, $175.7 \mathrm{~mm}$ SL. Hypostomus paranensis. Bolivia: ANSP 88424, 1, $248.5 \mathrm{~mm}$ SL. ANSP 95873, 4, 111.8-136.6 mm SL. Hypostomus plecostomus. Brazil: INPA 33663, 1, $178.7 \mathrm{~mm}$ SL. INPA 38694, 1, $184.0 \mathrm{~mm}$ SL. Guyana: CAS 56704, 2, 107.7-134.2 mm SL. Venezuela: SU 62517, 1, 183.5 mm SL. Hypostomus pyrineusi. Peru: ANSP 180718, 1, 175.8 mm SL. Hypostomus regani. Brasil: LBP 3188, 4, 123.7147.8 mm SL. Hypostomus soniae. Brazil: INPA 33974, 3, 132.5147.6 mm SL. INPA 35324, 1, 172.4 mm SL. Hypostomus tenuis. Suriname: RMNH 16198, 1, $196.1 \mathrm{~mm}$ SL, holotype of Hypostomus tenuis Boeseman, 1968: 64. Hypostomus watawata. Guyana: BMNH 1932.11.10.31, 261.2 mm SL, neotype of Hypostomus watawata Hancock, 1828: 246, designated by Boeseman, (1968: 71). RMNH 3101, 1, $120.7 \mathrm{~mm} \mathrm{SL}$, paralectotype of Hypostomus watawata Hancock, 1828: 246, designated by Boeseman, (1968: 71). Suriname: RMNH 21434, 1, 115.3 mm SL. RMNH 21435, 1, $135.5 \mathrm{~mm}$ SL. Isorineloricaria spinosissima. Ecuador. AMNH 58373, 10, 44.3-120.4 mm SL. BMNH 1898.11.4.32, 1, 357.6 mm SL, syntype of Plecostomus spinosissimus Steindachner, 1880: 98. Isorineloricaria villarsi. Colombia: ANSP 139262, 3, 114.9237.5 mm SL. CAS 13915, 6, 105-141.6 mm SL. NMW 44294, 1, 179.7 mm SL, syntype of Plecostomus villarsi Lütken, 1874: 211. Venezuela: ANSP 134482, 1, 205.5 mm SL. AMNH 242814, 1, 115.6 mm SL. CAS 64374, 1, $115.7 \mathrm{~mm}$ SL. CAS 64381, 1, $98.4 \mathrm{~mm}$ SL. USNM 121030, 1, $188.0 \mathrm{~mm}$ SL.

\section{Discussion}

The new species has a distinct coloration from all congeners. In Aphanotorulus ammophilus, A. emarginatus, $A$. gomesi, $A$. horridus, $A$. phrixosoma, and $A$. unicolor the lower and upper lobe of the caudal fin are completely covered with several series of transversely aligned conspicuous dark spots on the membrane and on the rays (Fig. 5). Other characteristic that distinguishes $A$. rubrocauda from the others species of Aphanotorulus is the absence of dark spots on the pelvic fin, although these are present in some specimens.

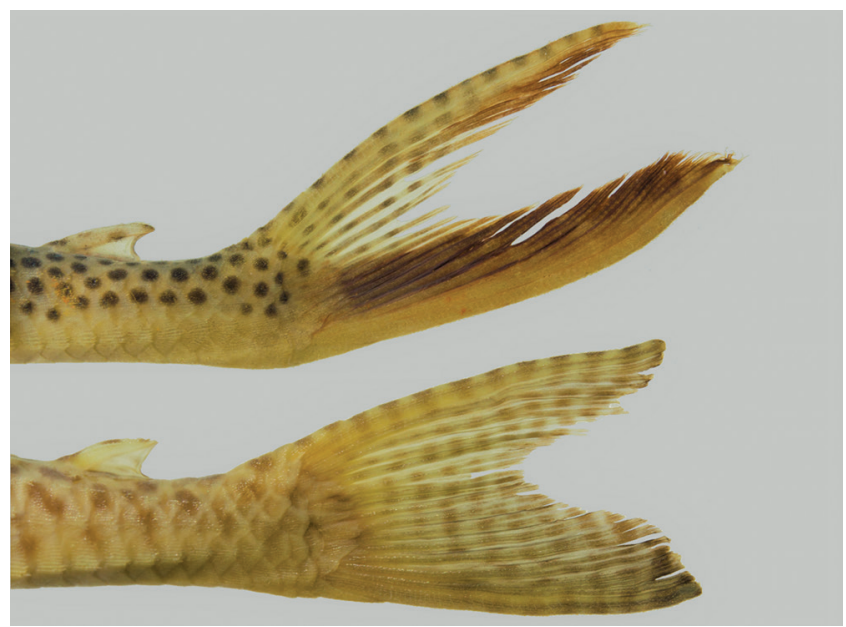

Fig. 5. Lateral view of caudal fin illustrating the coloration: Upper: Aphanotorulus rubrocauda MNRJ 39824, paratype, $132.2 \mathrm{~mm}$ SL. Lower: Aphanotorulus emarginatus INPA 36634, $147.3 \mathrm{~mm}$ SL.

Aphanotorulus rubrocauda also differs from its congeners by inhabiting a different type of environment. Whereas most Aphanotorulus species inhabit sandy beaches that are periodically formed on the margin or shores of the central channel of the white-water rivers, A. rubrocauda inhabits streams of clear to lightly-sediment loaded waters, with rapids with rocks and sandy substrate (Fig. 6). Aphanotorulus rubrocauda is currently only recorded from tributaries of the rio Aripuanã basin, mainly the rio Guariba, rio Madeirinha and rio Roosevelt. These rivers are inserted in a mosaic of Conservation Units of Amazonas State, Brazil.

The rio Aripuanã basin hosts a considerable diversity of fishes, with 26 new species described in the past two decades (Kullander, 1995; Ribeiro et al., 2011, Deprá et al., 2014; Zawadzki, Holanda Carvalho, 2014; Tencatt, Ohara, 2016), which indicates the need for strong conservation measures. However, the rio Aripuanã basin is one of the several rivers in the Amazon basin targeted for construction of hydroelectric dams. In addition to Dardanelos Hydropower, which is already built in the Aripuanã Municipality, Mato Grosso State, there are ongoing governmental projects for additional dams to be constructed on the rio Aripuanã and rio Roosevelt (Fearnside, 2015). This scenario may lead to environmental modifications that put this remarkable biodiversity at risk. 


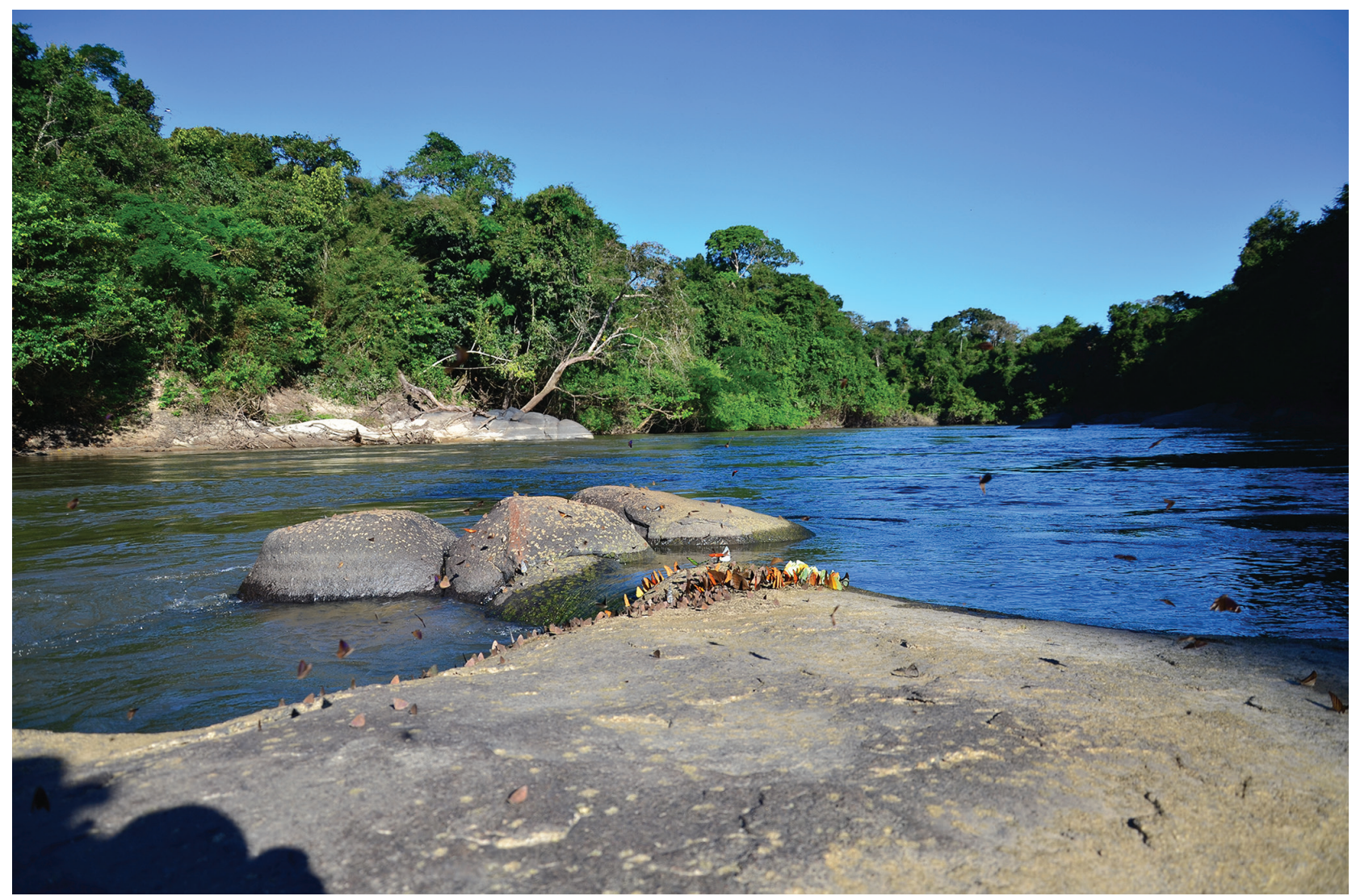

Fig. 6. Type locality of Aphanotorulus rubrocauda, Brazil, Amazonas State, Apuí Municipality, boulders on rapids 40 minutes above of the Comil farm, rio Madeirinha, rio Aripuanã basin. Photo by Willian Ohara.

\section{Acknowledgments}

We would like to acknowledge Scott Schaefer (AMNH), Mark Sabaj (ANSP), Carlos Lucena (MCP), Marcelo Britto (MNRJ), Osvaldo Oyakawa (MZUSP), Carla Pavanelli (UEM), Claudio Oliveira (UNESP-Botucatu), Carolina Doria (UNIR) and Richard Vari (in memoriam) (USNM) for hosting museum visits and loaning of material. Mark Sabaj Perez (ANSP), through iXingu Project, for the opportunity to visit some museums in the USA. Fabio Pupo (MNRJ) and Hugmar Pains da Silva (UEM) for providing images of the live specimen of Aphanotorulus rubrocauda and Aphanotorulus emarginatus, respectively. Douglas Bastos (INPA) for helping with the map and images of the holotype. Valéria Machado (UFAM), Wellington Pedroza (INPA) and Willian Ohara (MZUSP) for thorough discussions about the rio Aripuanã basin. Nathan Lujan for the revision of this manuscript. To our colleagues from INPA: Isabel M. Soares, Priscila Madoka Ito, Shizuka Hashimoto and Rafaela Ota for curatorial assistance. INPA and Nupélia/UEM provided logistical support. Financial support to ASO was provided by Conselho Nacional de Desenvolvimento Científico e Tecnológico (CNPq, process n. 141051/2013-2) and LRP and CHZ benefited from funds granted by CNPq, processes n. 474236/2004-8 and $n$. 310733/2013-8, respectively.

\section{References}

Armbruster JW. Phylogenetic relationships of the suckermouth armoured catfishes (Loricariidae) with emphasis on the Hypostominae and the Ancistrinae. Zool J Linn Soc. 2004; 141(1):1-80.

Armbruster JW, Page LM. Redescription of Aphanotorulus (Teleostei: Loricariidae) with description of one new species, A. ammophilus, from the Río Orinoco basin. Copeia. 1996; (2):379-89.

Boeseman M. The genus Hypostomus Lacépède, 1803, and its Surinam representatives (Siluriformes: Loricariidae). Zool Verhandel. 1968; 99:1-89.

Deprá GC, Kullander SO, Pavanelli CS, Graça WJ. A new colorful species of Geophagus (Teleostei: Cichlidae), endemic to the rio Aripuanã in the Amazon basin of Brazil. Neotrop Ichthyol. 2014; 12(4):737-46.

Fearnside PM. Hidrelétricas na Amazônia: impactos ambientais e sociais na tomada de decisões sobre grandes obras. Manaus: Editora do INPA; 2015.

Ferraris CJ, Jr. Check list of catfishes, recent and fossil (Osteichthyes: Siluriformes), and catalogue of siluriform primary types. Zootaxa. 2007; 1418:1-628.

Isbrücker IJH, Nijssen H. Aphanotorulus frankei, une espèce et un genre nouveaux de poisons-chats cuirassés du Basin du Rio Ucayali au Pérou (Pisces, Siluriformes, Loricariidae). Rev Fr Aquariol. 1983; 9:105-10. 
Kullander SO. Three new cichlid species from southern Amazonia: Aequidens gerciliae, A. epae and A. michaeli. Ichthyol Explor Freshw.1995; 6(2):149-70.

Lujan NK, Armbruster JW, Lovejoy NR, López-Fernández H. Multilocus molecular phylogeny of the suckermouth armored catfishes (Siluriformes: Loricariidae) with a focus on subfamily Hypostominae. Mol Phylogenet Evol. 2015; 82:269-88.

Oyakawa OT, Akama A, Zanata AM. Review of the genus Hypostomus Lacépède, 1803 from rio Ribeira de Iguape basin, with description of a new species (Pisces, Siluriformes, Loricariidae). Zootaxa. 2005; 921(1):1-7.

Pedroza WS, Ribeiro FRV, Teixeira TF, Ohara WM, Rapp PyDaniel LH. Ichthyofaunal survey of stretches of the Guariba and Roosevelt Rivers, in Guariba State Park and Guariba Extractive Reserve, Madeira River basin, Amazonas, Brazil. Check List. 2012; 8(1):8-15.

Ray CK, Armbruster JW. The genera Isorineloricaria and Aphanotorulus (Siluriformes: Loricariidae) with description of a new species. Zootaxa. 2016; 4072(5):501-39.

Ribeiro FRV, Pedroza WS, Rapp Py-Daniel LH. A new species of Nemuroglanis (Siluriformes: Heptapteridae) from the rio Guariba, rio Madeira basin, Brazil. Zootaxa. 2011; 2799:41-48.

Schaefer SA. The Neotropical cascudinhos: systematics and biogeography of the Otocinclus catfishes (Siluriformes: Loricariidae). Proc Acad Nat Sci Phila. 1997; 148:1-120.
Tencatt LFC, Ohara WM. Two new species of Corydoras Lacépède, 1803 (Siluriformes: Callichthyidae) from the rio Madeira basin, Brazil. Neotrop Ichthyol. 2016; 14(1):139-54.

Weber C. Hypostomus dlouhyi, nouvelle espèce de poisson-chat cuirassé du Paraguay (Pisces, Siluriformes, Loricariidae). Rev Suisse Zool. 1985; 92(4):955-68.

Weber C. Subfamily Hypostominae. In: Reis RE, Kullander SO, Ferraris CJ, Jr., organizers. Check list of the freshwater fishes of South and Central America. Porto Alegre: Edipucrs; 2003. p.351-72.

Zawadzki CH, Hollanda Carvalho P. A new species of the Hypostomus cochliodon group (Siluriformes: Loricariidae) from the rio Aripuanã basin in Brazil. Neotrop Ichthyol. 2014; 12(1):43-51.

Zawadzki CH, Weber C, Pavanelli CS. Two new species of Hypostomus Lacépède (Teleostei: Loricariidae) from the upper rio Paraná basin, Central Brazil. Neotrop Ichthyol. 2008; 6(3):403-12.
Submitted December 6, 2015

Accepted January 16, 2017 by Francisco Langeani 
